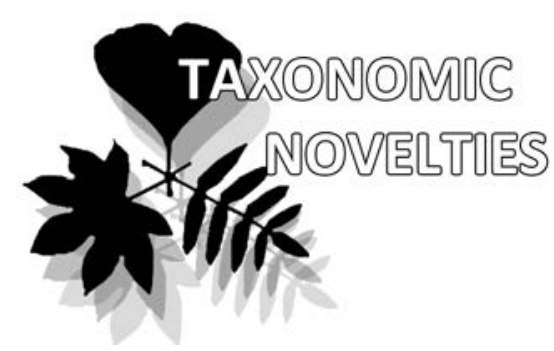

\title{
Diderma velutinum, a new species of Diderma (Myxomycetes) with large columella and triple peridium from Russia
}

Fedor M. Bortnikov ${ }^{1 *}$, Oleg N. Shchepin², Vladimir I. Gmoshinskiy ${ }^{1}$, Ilya S. Prikhodko ${ }^{2} \&$ Yuri K. Novozhilov ${ }^{2}$

Fedor M. Bortnikov ${ }^{1 *}$

e-mail: f.m.bortnikov@gmail.com

Oleg N. Shchepin ${ }^{2}$

e-mail: ledum_laconicum@mail.ru

Vladimir I. Gmoshinskiy

e-mail: rubisco@list.ru

Ilya S. Prikhodko ${ }^{2}$

e-mail: hypnothotep@gmail.com

Yuri K. Novozhilov

e-mail: yurinovozhilov@gmail.com

${ }^{1}$ Lomonosov Moscow State University, Faculty of Biology, Mycology and Algology Dept., Moscow 119234 Russia

${ }^{2}$ V.L. Komarov Botanical Institute RAS, Saint-Petersburg, Russia

* corresponding author

Manuscript received: 07.09.2018

Review completed: 25.10 .2018

Accepted for publication: 30.10 .2018

Published online: 31.10 .2018

\begin{abstract}
A B S T R A C T
A new species, Diderma velutinum, is described and illustrated by LM and SEM micrographs. Two specimens of this species were found in moist chamber cultures on the pieces of the bark of living tree of Phellodendron amurense, which was collected in July 2016 and July 2017 in the Kedrovaya Pad State Nature Biosphere Reserve (the Russian Far East). The main distinguishing features of this species are triple peridium, large spherical columella and ochraceous colour of sporangia clustered in dense groups. The partial $18 \mathrm{~S}$ rRNA gene sequences of $D$. velutinum differ considerably from all sequences of Diderma species available to the moment.
\end{abstract}

Ke ywords: Amoebozoa, COI, DNA barcoding, EF1A, morphology, Physarales, SEM, taxonomy, $18 \mathrm{~S}$ rRNA

\section{P E 3 Ю M E}

Бортников Ф.М., Щепин О.Н., Гмошинский В.И., Приходько И.С., Новожимов Ю.К. Diderma velutinum, новый виА рода Diderma (Мухоmycetes) с большой колонкой и трехслойным перидием из России. Новый виА Diderma velutinum описан и проимлюстрирован микрофотографиями, полученными с помощью светового и сканирующего электронного микроскопов. Ава образца этого вида были получены методом влажных камер на фрагментах коры живого дерева бархата амурского (Phellodendron amurense), собранных в июле 2016 и июле 2017 года в государственном природном биосферном заповеднике «Кедровая Падь» (Приморский Край). Основными отличительными особенностями этого виАа явАяются трехслойный перидий, большая сферическая колонка и охристая окраска спорангиев, собранных в плотные группы. Нуклеотилные последовательности фрагмента гена 18S рРНК нового виАа показывают значительные отличия От имеющихся последовательностей Аругих видов рода Diderma.

Ключевые слова: Amoebozoa, COI, EF1A, Physarales, АНК-баркодинг, морфология, СЭМ, таксономия, $18 \mathrm{~S}$ рРНК
Diderma is one of the three largest genera of myxomycetes and currently includes 82 species (Lado 2005-2018) of which 27 are recorded in Russia (unpublished data). During the study of biodiversity of myxomycetes in the Kedrovaya Pad State Nature Biosphere Reserve in 2016, in a moist chamber culture a collection of Diderma was found, which differed from all the described species of this genus. The second collection of this species was obtained in a moist chamber culture after additional sampling of substrates for moist chambers in July 2017 in the same locality.

In this paper we describe this new species of Diderma, including the morphological analysis of sporocarps and spores using the light (LM) and the scanning electron microscopy (SEM), and provide partial sequences of $18 \mathrm{~S}$ rRNA, COI and EF1A genes.

\section{MATERIAL AND METHODS}

\section{Isolates and morphology}

The moist chamber cultures were used to obtain a new species. This new species was described and illustrated by the first author at the Department of Mycology and Algo- logy of the Biological Faculty of the Lomonosov Moscow State University.

The sampling of the substrates for moist chamber cultures was carried out in July 2016 and 2017 in the same locality of the Kedrovaya Pad State Nature Biosphere Reserve. Small fragments of the bark of a living tree were cut out at about $1.5 \mathrm{~m}$ height, placed in paper bags and air-dried. In the laboratory, samples were evenly distributed over the bottom of Petri dishes above the filter paper and poured with distilled water. After a day, $\mathrm{pH}$ was measured with the $\mathrm{pH}$-meter "Aquilon $\mathrm{pH}-420$ " and excess water was drained off. The cultures were incubated at room temperature (18$22^{\circ} \mathrm{C}$ ) under diffused light for three months and checked for the presence of sporocarps of myxomycetes every 7-14 days, more often in the first 45 days. Sporocarps of the new species appeared within 50-70 days after the beginning of the moist chamber cultures. Plasmodium was seen only in the second setting of moist chamber cultures and after formation it quickly passed to sporangiogenesis. The macroscopic characteristics of air-dried sporocarps were studied with a Leica M80 stereomicroscope (with a 
Leica IC 80 HD camera). Some photos were taken with a Nikon D5200 digital camera with a Nikkor 105 mm 1:2.8G ED lens. The microscopic features of peridium, capillitium and spores were studied with a Leica DM 2500 microscope. The microscopic structures were measured with the program LAS EZ v. 3.1.1. The scanning electron micrographs were obtained with a JEOL JSM-6380LA scanning electron microscope (SEM) after sputtering with gold-palladium. Colour notations in parentheses are from the ISCC-NBS colour-name charts illustrated with centroid colours (Anonymous 2012).

\section{Analysis of partial 18S rRNA gene sequences}

The first part of the $18 \mathrm{~S}$ rRNA gene widely used as the most perspective DNA barcode for myxomycetes (Schnittler et al. 2017) was obtained for the both specimens of the new Diderma species using primers S1/SU19R as described elsewhere (Shchepin et al. 2016), as well as partial sequences of elongation factor 1 alpha gene (EF1A, primers $\mathrm{PB} 1 \mathrm{~F} /$ PB1R) and cytochrome c oxidase subunit I gene (COI, primers COMF/COMRs). All new sequences were deposited in GenBank. Additionally, to check the level of genetic divergence of the new species the same region of the $18 \mathrm{~S}$ rRNA gene of five other Diderma species was sequenced and 136 sequences of the Diderma species were retrieved from the quality-checked sequence collection (Borg Dahl et al. 2017). Percentage of the genetic similarity of the sequences was calculated as $100 *$ (matching columns) / (alignment length - terminal gaps) using usearch_global command in VSEARCH 2.8.0 (Rognes et al. 2016).

\section{TAXONOMY}

Diderma velutinum Bortnikov, sp. nov. Figs. 1-16

MycoBank: 827750

GenBank: MH714785, MH714786, MH717084-MH717087

Holotype: LE 318752

Description. Sporocarps grouped in small dense groups, globose or subglobose, often slightly angular from mutual compression, sessile, $0.5-0.9 \mathrm{~mm}$ in diameter, immature vivide orange (v.O 48), mature pale yellow (p.Y 89) to grayish greenish yellow (gy.gY 105). Hypothallus inconspicuous. Peridium three-layered, all layers closely appressed, break up together. Outer layer thin, membranous, translucent. Middle layer thick, fragile enough, yellowishochraceous, composed by closely adherent lime granules. Inner layer membranous, in upper part very thin and almost inconspicuous to absent, thicker and darker downwards, up to the dark hazel-brown, usually well distinguishable. Dehiscence not observed, but probably irregular. Columella concolorous with the peridium, well developed, large, spherical or subspherical, reaches about $1 / 2$ (up to $2 / 3$ ) height of sporangia, covered by thin membrane, filled with lime granules about $1.5 \mu \mathrm{m}$ in diameter. Columella and peridium rarely with no more than 3-5 calcareous spike-like protuberances per sporangium that even more rarely can merge into column. Capillitium abundant, radiating from columella to inner peridium, but in most cases threads break at the ends and so spore mass is separated from peridium by free space. Capillitium threads hyaline, about 3-4.5 $\mu \mathrm{m}$ in diameter, wavy, branched and anastomosed, sometimes with membranous extensions at branching points, threads surface under SEM smooth or with small papulae. Spores in mass brownish black (brBlack 65), brown (d.Br 59) in transmitted light, sometimes slightly lighter on the one side, (10.6-) $12(-13.2) \mu \mathrm{m}$ in diameter (Mean: 12.15, SD: 0.51, $\mathrm{n}=85)$, densely warted. Warts arranged irregularly, under SEM appear clavate. Plasmodium yellowish-ochraceous to deep yellow-orange.

Holotype: Russian Federation, Primorsky Territory, Kedrovaya Pad State Nature Biosphere Reserve, 4306'47.3"N $131^{\circ} 30^{\prime} 57.5^{\prime \prime} \mathrm{E}, 96 \mathrm{~m}$ a.s.l., mixed forest dominated by Abies holopbylla Maxim., Quercus mongolica Fisch. ex Ledeb., Phellodendron amurense Rupr. and Betula sp., on bark of living Phellodendron amurense covered by mosses, in moist chamber culture (mcc), $\mathrm{pH}=5.83$, bark sampling 19.07.2016, mcc starting 14.09.2016, sporangia sampling 2.11.2016 and 23.11.2016, leg. Bortnikov F.M., LE 318752. A fragment of the type material was deposited in the collection of Myxomycetes of the Department of Mycology and Algology of Biological Faculty of Lomonosov Moscow State University (No. 8240).

Paratype: the same location and substrate, in moist chamber culture, bark sampling 24.07.2017, mcc starting 9.02.2018, sporangia sampling 10.04.2018 and 30.04.2018, leg. Bortnikov F.M., LE 318753.

Etymology: from latin "velutinus" - velvety; reference to the substrate on which this species was found (Phellodendron amurense in Russian is also known as "Amur velvet" because of the soft surface of the cork bark).

DNA barcode. Comparison of the DNA barcode sequences of Diderma velutinum (first part of the $18 \mathrm{~S}$ rRNA gene, GenBank accessions MH714785 and MH714786) to 143 sequences of 18 other species of Diderma showed that they are not more than $96 \%$ similar to Diderma sequences available to the moment (Table 1), with D. umbilicatum being the closest match. Additionally, partial EF1A and COI gene sequences for holotype and paratype were located in the GenBank (MH717084-MH717087). Sequences of 18S rRNA gene and EF1A are identical in both specimens of D. velutinum, while COI have six mismatches.

\section{DISCUSSION}

The three-layered peridium with closely appressed layers, densely grouped subglobose to globose sporocarps which are bright orange when immature and yellowish-ochraceous when matured, the large spherical yellow columella, the hyaline colourless capillitium and warted spores about $12 \mu \mathrm{m}$ in diameter are the diagnostic features of Diderma velutinum.

The new species differs in a number of important characters from other species that have sessile globose and subglobose sporangia with the yellowish, reddish brown or ochraceous peridium and more or less developed columella: D. albocolumella A.C.C. Bezerra \& L.H. Cavalc., D. ochraceum Hoffm., D. sauteri (Rostaf.) E. Sheld., D. simplex (J. Schröt.) E. Sheld. and D. testaceum (Schrad.) Pers. (Bezerra \& Cavalcanti 2010, Martin \& Alexopoulos 1969) (Table 2). The former species described from Brazil (Bezerra \& Cavalcanti 2010 ) is similar to the new species, because it has a triple peridium, a large spherical columella and warted spores 10.5- 

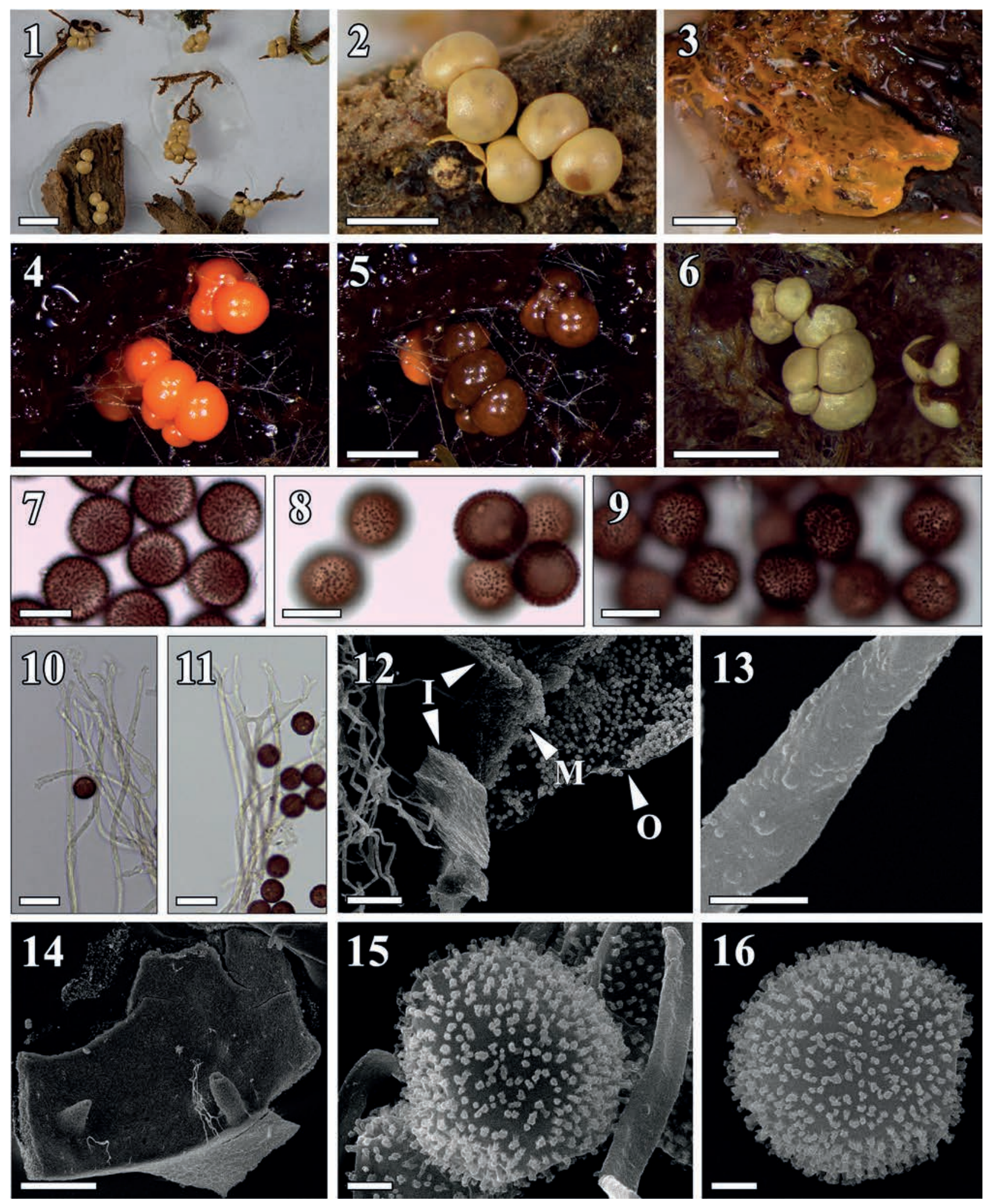

Figures 1-16 Diderma velutinum: Holotype LE 318752 (Figs. 1, 2, 7, 8, 10, 12, 15) and paratype LE 318753 (Figs. 3-6, 9, 11, 13, 14, 16). 1. Dense small groups of sporocarp. 2. Sporocarps. Large spherical columella is seen in a sporocarp with broken peridium. 3. Plasmodium. 4-6. Different stages of maturation of sporocarps. 7-9. Spores under LM. 10, 11. Threads of capillitium under LM. 12. Triple peridium under SEM. The arrows indicate the inner $(\mathrm{I})$, middle $(\mathrm{M})$ and outer $(\mathrm{O})$ lavers of the peridium. 13. The surface of the capillitial thread under SEM. 14. The inner surface of the peridium under SEM. Outgoing threads of capillitium and calcareous protuberances are visible. 15. Spores and capillitial thread under SEM. 16. Spore under SEM. Scale bars: Figs. 1, 3. 2 mm; Fig. 2, 4-6. 1 mm, Figs. 7-9. 10 mm; Figs. 10-12. $20 \mu \mathrm{m}$; Figs. 13, 15, 16. $2 \mu \mathrm{m}$; Fig. 14. $100 \mu \mathrm{m}$. 
Table 1. Similarity (\%) of partial $18 \mathrm{~S}$ rRNA gene sequences of Diderma velutinum to other Diderma species calculated with VSEARCH 2.8.0. Sequences obtained in present study are marked in bold.

\begin{tabular}{lll}
\hline Species & Similarity $\%$ & GenBank Accession \\
\hline Diderma umbilicatum & $96-95.9$ & MH714787, KP323371 \\
D. meyerae & $93.2-91.8$ & KR029670, KU198051, KU198050 and 15 more \\
D. microcarpum & $93-92.2$ & KU198063, JQ898093, KU198060 and 12 more \\
D. niveum & $92.4-90.5$ & KU198067, KU198068, KR029708 and 32 more \\
D. globosum var. europaeum & $91-89.3$ & KU198043, KU198044, KU198047 and 16 more \\
D. montanum & 89.1 & KT358690 \\
D. radiatum & $86-85.8$ & KM977855, MH714788 \\
D. hemisphaericum & $85.3-84.1$ & MH714789, KM977853 \\
D. deplanatum & $85.3-76.4$ & KM977851, KF743863, KF743864 \\
D. subocbraceum & 85.1 & MG696637 \\
D. fallax/Lepidoderma peyerimboffi & $85-84.7$ & KR029660, KU198040, JQ898089 and 14 more \\
D. testaceum & 85 & MH714790 \\
D. alpinum & $84.2-82.2$ & JQ898088, KR029646, KU198031 and 13 more \\
D. chondrioderma & 84 & KM977850 \\
D. spumarioides & $83.9-83.5$ & KJ6514791, MH714792, MH714793 \\
D. pseudotestaceum & 82.7 & KT731233 KJ659864, KJ659867 \\
D. cor-rubrum & 80.6 & KJ659863, KJ659865 \\
D. cattiense & 79.4 & KT731234 \\
D. miniatum & 73.8 &
\end{tabular}

Table 2. Comparison of morphological characters of Diderma velutinum and five other similar species of Diderma

\begin{tabular}{|c|c|c|c|c|c|c|}
\hline Characters & $\begin{array}{l}\text { Diderma } \\
\text { velutinum }\end{array}$ & $\begin{array}{l}\text { Diderma } \\
\text { albocolumella }\end{array}$ & $\begin{array}{l}\text { Diderma } \\
\text { ochraceum }\end{array}$ & Diderma sauteri & Diderma simplex & $\begin{array}{l}\text { Diderma } \\
\text { testaceum }\end{array}$ \\
\hline $\begin{array}{l}\text { Sporotheca } \\
\text { diam. }(\mathrm{mm})\end{array}$ & $0.5-0.9$ & $0.3-0.8$ & $0.4-1.0$ & $0.6-1.0$ & $0.2-0.8$ & $0.7-1$ \\
\hline $\begin{array}{l}\text { Shape of } \\
\text { sporotheca }\end{array}$ & $\begin{array}{l}\text { globose to sub- } \\
\text { globose, often } \\
\text { slightly angular }\end{array}$ & $\begin{array}{l}\text { hemispheric-de- } \\
\text { pressed to discoid, } \\
\text { slightly umbilica- } \\
\text { ted at the top }\end{array}$ & $\begin{array}{l}\text { globose to sub- } \\
\text { globose, some- } \\
\text { times as short } \\
\text { plasmodiocarps } \\
\end{array}$ & $\begin{array}{l}\text { globose to } \\
\text { subglobose }\end{array}$ & $\begin{array}{l}\text { subglobose, } \\
\text { pulvinate or } \\
\text { depressed }\end{array}$ & $\begin{array}{l}\text { globose to sub- } \\
\text { globose, some- } \\
\text { times depressed } \\
\text { to discoid } \\
\end{array}$ \\
\hline $\begin{array}{l}\text { Colour of } \\
\text { sporotheca }\end{array}$ & $\begin{array}{l}\text { pale yellow to } \\
\text { grayish and } \\
\text { greenish yellow }\end{array}$ & $\begin{array}{l}\text { bright yellowish- } \\
\text { brown }\end{array}$ & deep ochraceous & $\begin{array}{l}\text { pinkish-gray to } \\
\text { light reddish- } \\
\text { brown }\end{array}$ & $\begin{array}{l}\text { brown or brick } \\
\text { red to ochraceous }\end{array}$ & $\begin{array}{l}\text { flesh-colored or } \\
\text { light-pinkish- } \\
\text { white }\end{array}$ \\
\hline Peridium & three-layered & three-layered & double-layered & double-layered & single-layered & double-layered \\
\hline $\begin{array}{l}\text { Shape of } \\
\text { columella }\end{array}$ & $\begin{array}{l}\text { globose to sub- } \\
\text { globose, } 1 / 2-2 / 3 \\
\text { of the sporotheca }\end{array}$ & $\begin{array}{l}\text { subglobose, } \\
1 / 3-1 / 4 \text { of the } \\
\text { sporotheca }\end{array}$ & poorly developed & $\begin{array}{l}\text { small, often } \\
\text { reduced }\end{array}$ & $\begin{array}{l}\text { dome-shaped, } \\
\text { often reduced }\end{array}$ & $\begin{array}{l}\text { dome-shaped to } \\
\text { hemispherical }\end{array}$ \\
\hline $\begin{array}{l}\text { Colour of } \\
\text { columella }\end{array}$ & pale yellow & grayish white & NA & reddish-brown & $\begin{array}{l}\text { brown or brick } \\
\text { red to ochraceous }\end{array}$ & $\begin{array}{l}\text { pinkish-brown or } \\
\text { alutaceous }\end{array}$ \\
\hline \begin{tabular}{l|} 
Colour of \\
capillitium in \\
transmitted light
\end{tabular} & hyaline & $\begin{array}{l}\text { violet brown, } \\
\text { with hyaline } \\
\text { extremities }\end{array}$ & $\begin{array}{l}\text { dark yellowish } \\
\text { brown, with hya- } \\
\text { line extremities }\end{array}$ & $\begin{array}{l}\text { light violet or } \\
\text { hyaline }\end{array}$ & $\begin{array}{l}\text { hyaline to light- } \\
\text { colored }\end{array}$ & $\begin{array}{l}\text { hyaline to light- } \\
\text { colored }\end{array}$ \\
\hline \begin{tabular}{l|} 
Colour of \\
spores in mass
\end{tabular} & brownish black & dark brown & black & black & dark brown & black \\
\hline $\begin{array}{l}\text { Colour of } \\
\text { spores in trans- } \\
\text { mitted light }\end{array}$ & brown & $\begin{array}{l}\text { dark to yellowish } \\
\text { brown }\end{array}$ & $\begin{array}{l}\text { dark yellowish } \\
\text { brown }\end{array}$ & dark brown & light violet brown & dark brown \\
\hline $\begin{array}{l}\text { Spore diam. } \\
(\mu \mathrm{m})\end{array}$ & $10.6-13.2$ & $10.5-13.0$ & $9.0-11.0$ & $12-13$ & $8-11$ & $8-9$ \\
\hline $\begin{array}{l}\text { Spore } \\
\text { ornamentation }\end{array}$ & $\begin{array}{l}\text { irregularly } \\
\text { covered with } \\
\text { baculate warts }\end{array}$ & verrucose & $\begin{array}{l}\text { densely and un- } \\
\text { evenly covered } \\
\text { with large short } \\
\text { warts } \\
\end{array}$ & spinose & \begin{tabular}{|l|} 
minutely warted \\
or spinose, some- \\
times with groups \\
of darker warts \\
\end{tabular} & $\begin{array}{l}\text { almost smooth or } \\
\text { minutely warted }\end{array}$ \\
\hline
\end{tabular}

$13.0 \mu \mathrm{m}$ in diameter. However, it has flattened sporangia grouped in more sparse groups. In addition, the peridium of $D$. albocolumella is bright yellowish-brown and capillitium violet-brown. $D$. ochraceum shares with $D$. velutinum the deep ochraceous colour of the peridium, but differs in its reduced columella, the double-layered peridium and smaller spores (9-11 $\mu \mathrm{m}$ vs. 11-13 in D. velutinum). In addition, the spore ornamentation with densely and unevenly distributed large short warts as seen with SEM (Schnittler et al. 2010, Moreno et al. 2018) differs from more evenly distributed baculate warts of D. velutinum (Fig. 15-16). D. ochraceum var. izawae Y. Yamam. \& Nann.-Bremek. shares with D. velutinum spikelike outgrowths, which sometimes connect the columella and peridium but, as well as D. ochraceum Hoffm., it differs well by other attributes (Yamamoto \& Nannenga-Bremekamp 1995).

The brown-reddish, yellowish and pale ochraceous spo- 
rocarps of $D$. sauteri, D. testaceum and $D$. simplex are slightly similar to those of $D$. velutinum, but the former and the second species have the double-layered peridium and $D$. simplex has the single-layered peridium. In addition $D$. testaceum and D. simplex have smaller spores (8-9 and 8-11 $\mu \mathrm{m}$ respectively) (Martin \& Alexopoulos 1969).

DNA barcode produced for D. velutinum in this study is at least $4 \%$ different from all other Diderma sequences available to the moment, with an intraspecific sequence similarity threshold being estimated for dark-spored myxomycetes as $99.1 \%$ similarity for the targeted $18 \mathrm{~S}$ rDNA region (Borg Dahl et al. 2017).

Thus, we believe that the taxonomic status of our collections is undeniable, and they represent a new species for science.

\section{ACKNOWLEDGEMENTS}

The establishment of the collection of myxomycetes of the Department of Mycology and Algology of the Biological Faculty of the Lomonosov Moscow State University (MSU) was supported by a Russian Science Foundation project № 14-50-00029. Work on the collection and identification of the material was made in the framework of the State task of MSU, part 2 (topic number AAAA-A16-116021660). DNA sequencing was supported by Russian Foundation for Basic Research (project 18-04-01232 A) and state task of BIN RAS (AAAA-A18-118031290108-6). In addition, we acknowledge the use of equipment of the Core Facility Center "Cell and Molecular Technologies in Plant Science" at the Komarov Botanical Institute RAS (St. Petersburg). The first author also thanks the staff of the Land of the Leopard National Park for the assistance in fieldwork organization.

\section{LITERATURE CITED}

Anonymous 2012. NBS/ISCC Colour System. Original and Improved 267 Colour Centroids. Washington, Inter-Society Colour Council. National Bureau of Standards. http:// tx4.us/nbsiscc.htm (accessed July 2018).
Bezerra, A.C.C. \& L.D.H. Cavalcanti 2010. Diderma albocolumella (Myxomycetes), a new species in the Brazilian Atlantic Forest. Rodriguésia 61(1):105-108.

Borg Dahl, M., A.D. Brejnrod, M. Unterseher, T. Hoppe, Y. Feng, Y.K. Novozhilov, S.J. Sørensen \& M. Schnittler 2017. Genetic barcoding of dark-spored myxomycetes (Amoebozoa) - identification, evaluation and application of a sequence similarity threshold for species differentiation in NGS studies. Molecular Ecology Resources 18(2):306-318.

Lado, C. 2005-2018. An on line nomenclatural information system of Eumycetozoa. Real Jardin Botanico, CSIC. Madrid, Spain. http://www.nomen.eumycetozoa.com (accessed July 2018).

Martin, G.W. \& C.J. Alexopoulos 1969. The Myxomycetes. University of Iowa Press, Iowa City, $561 \mathrm{pp}$.

Moreno, G., Á. López-Villalba, S.L. Stephenson \& A. Castillo 2018. Lepidoderma cristatosporum, a new species of myxomycete from Australia. Mycoscience 59(5):386-391

Rognes, T., T. Flouri, B. Nichols, C. Quince \& F. Mahé 2016. VSEARCH: a versatile open source tool for metagenomics. PeerJ 4:e2584. doi: 10.7717/peerj.2584

Schnittler, M., M. Unterseher, T. Pfeiffer, Yu. K. Novozhilov \& A.M. Fiore-Donno 2010. Ecology of sandstone ravine myxomycetes from Saxonian Switzerland (Germany). Nova Hedwigia 90(3-4):277-302.

Schnittler, M., O.N. Shchepin, N.H.A. Dagamac, M. Borg Dahl \& Y. K. Novozhilov 2017. Barcoding myxomycetes with molecular markers: challenges and opportunities. Nova Hedwigia 104(1-3):323-341.

Shchepin, O.N., Y.K. Novozhilov \& M. Schnittler 2016. Disentangling the taxonomic structure of the Lepidoderma chailletii-carestianum species complex (Myxogastria, Amoebozoa): genetic and morphological aspects. Protistology 10(4):117-129.

Yamamoto, Y. \& N.E. Nannenga-Bremekamp 1995. Diderma ochraceum var. izawae, a new Myxomycete from New Zealand. Proceedings of the Royal Netherlands Academy of Arts and Sciences 3(98):327-328. 